\title{
EVALUATION OF FOOD TYPE INTRODUCED TO THE HONEYBEE COLONIES ON CONTAMINATION OF EXTRACTED HONEY WITH MICROORGANISMS
}

\author{
Rawdaa R. Khalil'; M.E.M. El-Sherif ${ }^{1}$ and N.Y. Abd-Elgfar ${ }^{2}$ \\ 1- Plant Protection Dept., Fac. of Agric., Ain Shams Univ., Cairo, Egypt \\ 2- Plant Pathogen Dept., Fac. of Agric., Ain Shams Univ., Cairo, Egypt
}

[58]

Keywords: Honey, Contamination, Microorganisms, Bacteria, Fungi, Yeasts, Plant extracts

\section{ABSTRACT}

The aim of the present work to study the effect of food types (sugar syrup fortified with Garlic (Allium sativum), Lemon (Citrus limon), Garlic plus Lemon), pollen grains and plain sugar syrup (1:1)) on contamination of honey with bacteria, fungi and yeasts. The data indicated that application of sugar syrup plus extracts of garlic, lemon, garlic plus lemon or bee pollen led to decrease population of bacteria, fungi and yeasts compared with control treatment (plain sugar syrup 1:1). The fungi were the least population in all the treatments compared with bacteria and yeasts, meanwhile population of bacteria were moderately and the yeasts were the most occurrence. Garlic plus lemon treatment was the most effective against population of microorganisms, but garlic and lemon separate were moderately effective and bee pollen treatment was the least effective compared with other treatments. According to isolation and identification procedures, three bacterial species (Bacillus brevis, Bacillus cereus and Clostridium botulism), four fungal species (Aspergillus apis, Aspergillus niger, Cladosporium sp. and Penicillium sp.) and three yeasts species (Debaromyces sp., Lipomyces sp. and Saccharomyces sp.) were determined according to cultural, morphological and physiological characters. Cladosporium botulism bacterium was the most frequency compared with other bacteria species, but Aspergillus apis fungus was the most frequency compared with other fungi species and Lipomyces sp. was the most frequency compared with other yeasts.

\section{INTRODUCTION}

Honey bee (Apis mellifera L.) is a highly appreciated and economically important domestic animal. They collecting nectar and pollen and also pollinate several important crops. Several crops are dependent on honeybee pollination to yield economic value (Aizen et al 2008). Honey contains fewer microorganisms than other naturalfoods. Microorganisms present in honey are those that can withstand sugar, acidity and other antimicrobial components of honey. Conventional microbiology and PCR based studies reported several species of cultivable and non-cultivable bacteria, yeasts and filamentous fungi associated with honeys of different geographical and botanical organ (Olivieri et al 2012 and Sinacori et al 2014). Molds and yeasts were quantified by counting in petri dishes containing potato dextrose agar and incubated for seven days. Total and thermotolerant coliforms were quantified by the technique of multiple tube fermentation, then determining the most probable number program (Matos et al 2011).

There are some sources of microbial contamination in honey. The primary sources of microbial contamination are the nectar, pollen, the digestivetracts of honey bees, dust, earth and air. These sources are very difficult to control. The other sources of microbial contamination in honey are post-harvest sources include dust, wind, containers, equipment and human (Olaiten et al 2007 and Kim et al 2011). These microbes could be placed in three categories: microorganisms, that are commonly found in honey i.e. certain strains of yeast and spore-forming bacteria (Whadan, 1998), microorganisms that indicate sanitary or commercial quality i.e. coliform or yeast (Sinacor et al 
2014) and microorganisms that infer certain conditions (e.g. germination and growth in a non heated food products) (Snowdon and Cliver, 1996). The microorganisms present in honey include bacteria, yeast and mold. Members of air genera Bacillus, Clostridium and Micrococcus are common in air and dust and they can easily enter into honey. Most bacteria and other microbes are present in dormant state. Spore-forming bacteria can survive in honey for a long period of time. The presence of Clostridium botulinum spores in honey has been reported extensively and numerous honey samples have tested positive for $C$. botulinum spores and toxins (Tanzi and Gabay, 2002). Honey naturally contains different osmo-tolerant yeast which can cause undesirable fermentation. The low moulds counts may survive but do not tend to grown in honey (Piana et al 1991).

The objective of this study was to evaluate the effect of food type on population and frequency of fungi, bacteria and yeasts in honey.

\section{MATERIALS AND METHODS}

\section{Honey samples}

This experiment was carried out in honey bee colonies in the apiary belong to Faculty of Agriculture, Ain Shams University, during summer season (June to August, 2014). Honey bee colonies were fed during the experimental period on sugar syrup (1 sugar: 1 water) fortified with extracts of $10 \mathrm{~g}$ of (Garlic (Allium sativum), Lemon (Citrus limon), Garlic plus Lemon) or pollen grains and plain sugar syrup) to study the effect of food type on population of bacteria, fungi and yeasts in honey samples extracted. The plant extracts were mixed with sugar syrup (1 sugar: 1 water) and sugar syrup alone was applied as control treatment (untreated check). Four honeybee colonies were used for each treatment. Samples of honey were collected at end of the experiment to study the following:

\section{Isolation and population of microorganisms} contaminating honey samples

Nutrient agar (NA), water agar (WA) and nutrient yeast extract dextrose agar (NYDA) media were applied to study isolation and population of bacteria, fungi and yeasts, respectively. Honey suspension was prepared by adding $10 \mathrm{~g}$ of honey to flask contained $90 \mathrm{ml}$ of sterilized distilled water and was shaken at $1000 \mathrm{rpm}$ for $2 \mathrm{hr}$. One $\mathrm{ml}$ of the prepared solutions was added onto sterilized petri dish and about $20 \mathrm{ml}$ of previously melted specific agar media $\left(45-50^{\circ} \mathrm{C}\right)$ were added to it (Mehrotra et al 1996; Barnett \& Hunter 1987 and Fahy \& Persley 1983). Four plates were used as replicates for each particular treatment. After gentle rotation, inoculated plates were incubated at $28^{\circ} \mathrm{C}$ for 2-5 days. Number of bacteria, fungi and yeasts colonies were recorded per sample to calculate their population. Single colonies were picked up and transferred to another slant media. Obtained bacteria, fungi and yeasts isolates were kept in a refrigerator for further studies.

\section{Identification of microorganism contaminating of honey samples}

Selected colonies of bacteria, fungi and yeasts were transferred to sterilized petri dishes contained specific medium for purification by steaked plate technique and incubated at $28^{\circ} \mathrm{C}$ for 2.5 days. According to cultural, morphological and physiological characters, selected bacteria (Schaad, 1980 and Bochner, 1991), fungi (Barnett and Hunter, 1987); and yeasts (Kreger-Van, 1984; Odds, 1988 and Barnett et al 2000) were kindly identification in the microbiology center, Faculty of Science, Al-Azhar University, Cairo, Egypt.

\section{Statistical analysis}

Obtained data were statistically analyzed by using a randomized complete block design in factorial arrangement according to Sndecor and Cocheran (1990). For separation between means, least significant difference (at $5 \%$ probability) was applied.

\section{RESULTS AND DISCUSSION}

\section{Effect of food type on microorganisms popu- lation in honey samples}

Five solution of sugar syrup plus extracts of (garlic, lemon, garlic plus lemon, bee pollen and plain sugar syrup) were applied for honey bee colonies to study their effect on population of bacteria, fungi and yeasts in extracted honey samples. As shown in (Fig. 1) population of bacteria, fungi and yeasts were decreased with application of garlic, lemon, garlic plus lemon, and bee pollen solution compared with feeding honey bee colonies on plain sugar syrup as control treatment (untreated check), where the population of microorganisms ranged from 0.00 to 2.38 colony/ sample as com- 


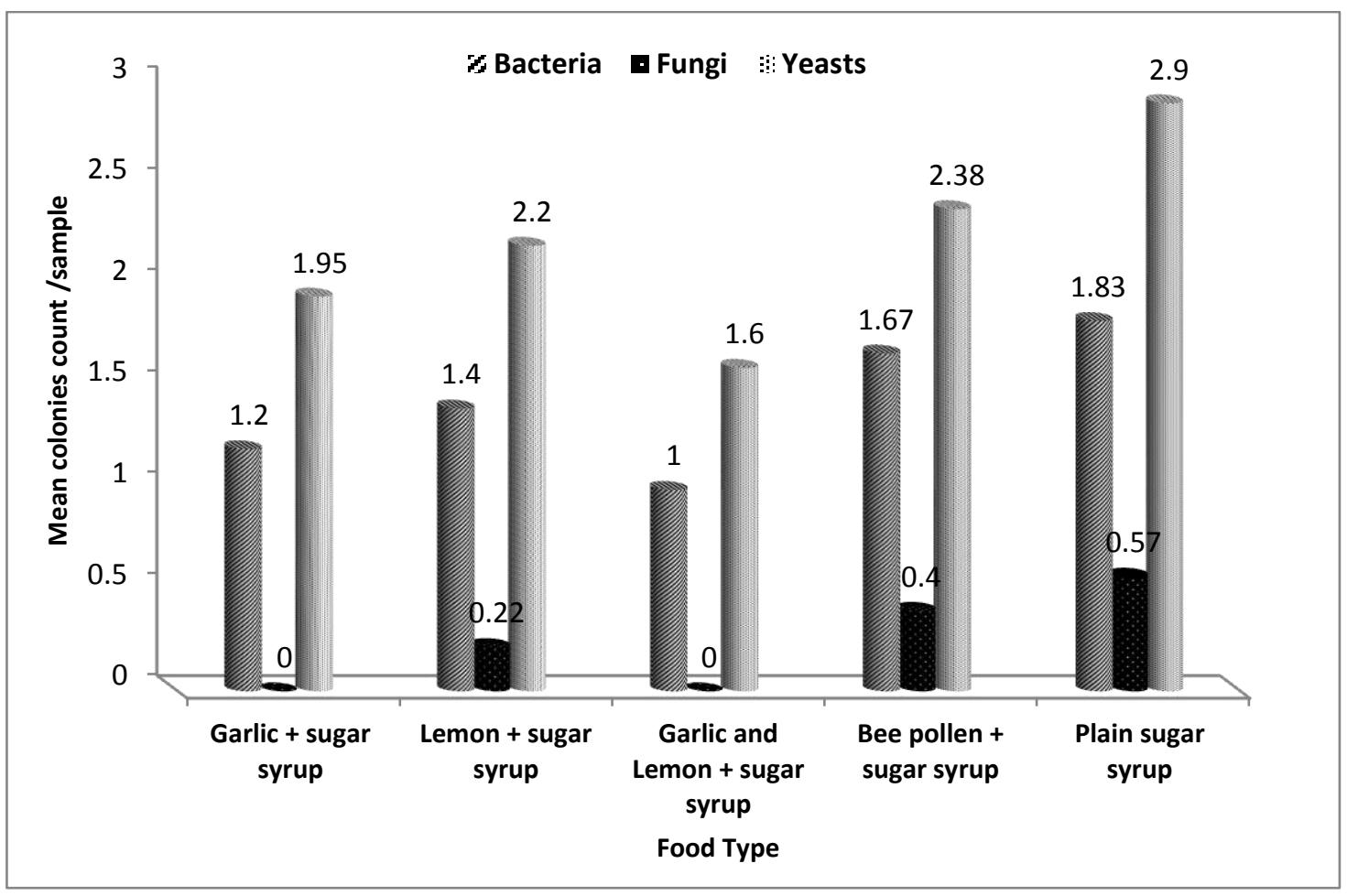

Fig. 1. Relationship between populations of bacteria, fungi and yeasts and food type introduced to the honeybee colony in honey samples collected from the apiary of Faculty of Agriculture, Ain Shams University.

pared with control treatment (untreated check) which ranged from 0.57 to 2.90 colony/sample. The fungi were the least population with all the treatments compared with bacteria and yeasts, where the population was $(1.0-1.67,0.00-0.40$ and 1.60-2.38 colony/sample) for bacteria, fungi and yeasts, respectively. Garlic plus lemon treatment was the most effective against population of bacteria, fungi and yeasts in honey samples, where the population was ranged from 0.00 to 1.60 colony/sample, but garlic and lemon treatments separate were moderately effective on microorganisms population, where the population was $(0.20-1.95$ and $0.22-2.20$ colony/sample) for garlic and lemon treatment, respectively, and bee pollen treatment was the least effective on population of bacteria, fungi and yeasts, where the population was ranged from 0.40 to 2.38 colony/sample.

Matos et al (2011) found that molds and yeasts occurred on average of $71.9 \times 10^{2}$ colony forming units (cfu)/grm. Filamentous fungi occurred in $80 \%$ samples (average $2.8 \times 10^{2} \mathrm{cfu} / \mathrm{ml}$ ), while yeasts occurred in $100 \%$ of the samples (average $62.2 \times 10^{2} \mathrm{cfu} / \mathrm{ml}$ ). They also found that five sam- ples (33.3\%) had total coliforms and thermotolerant and three of these were within the limits tolerated by low. Estervinho et al (2012) mentioned that yeasts and molds were detected in low counts, with mean values obtained of $2.5 \mathrm{cfu} / \mathrm{g}$. and the value of total aerobic mesphiles obtained from honey was established in $1.3 \times 10^{2} \mathrm{cfu} / \mathrm{g}$. Rozanska and Osek (2012) showed that honey samples displayed different levels of microbiological contamination. The mean of total number of aerobic bacteria varied from $1.9 \times 10^{2} \mathrm{cfu} / \mathrm{g}$ to $4.6 \times 10^{3}$ $\mathrm{cfu} / \mathrm{g}$. depending on the type of honey.

2. Effect of food types introduced to the honeybee colonies on microorganisms frequency in honey samples

The frequency (\%) of bacteria, fungi and yeasts for honey samples after feeding honey bee colonies on sugar syrup plus extracts of garlic, lemon, garlic plus lemon, bee pollen and plain sugar syrup is illustrated in (Figs. 2, 3 and 4). According to identification procedures, three bacteria types (Bacillus brevis, Bacillus cereus and Clostridium 


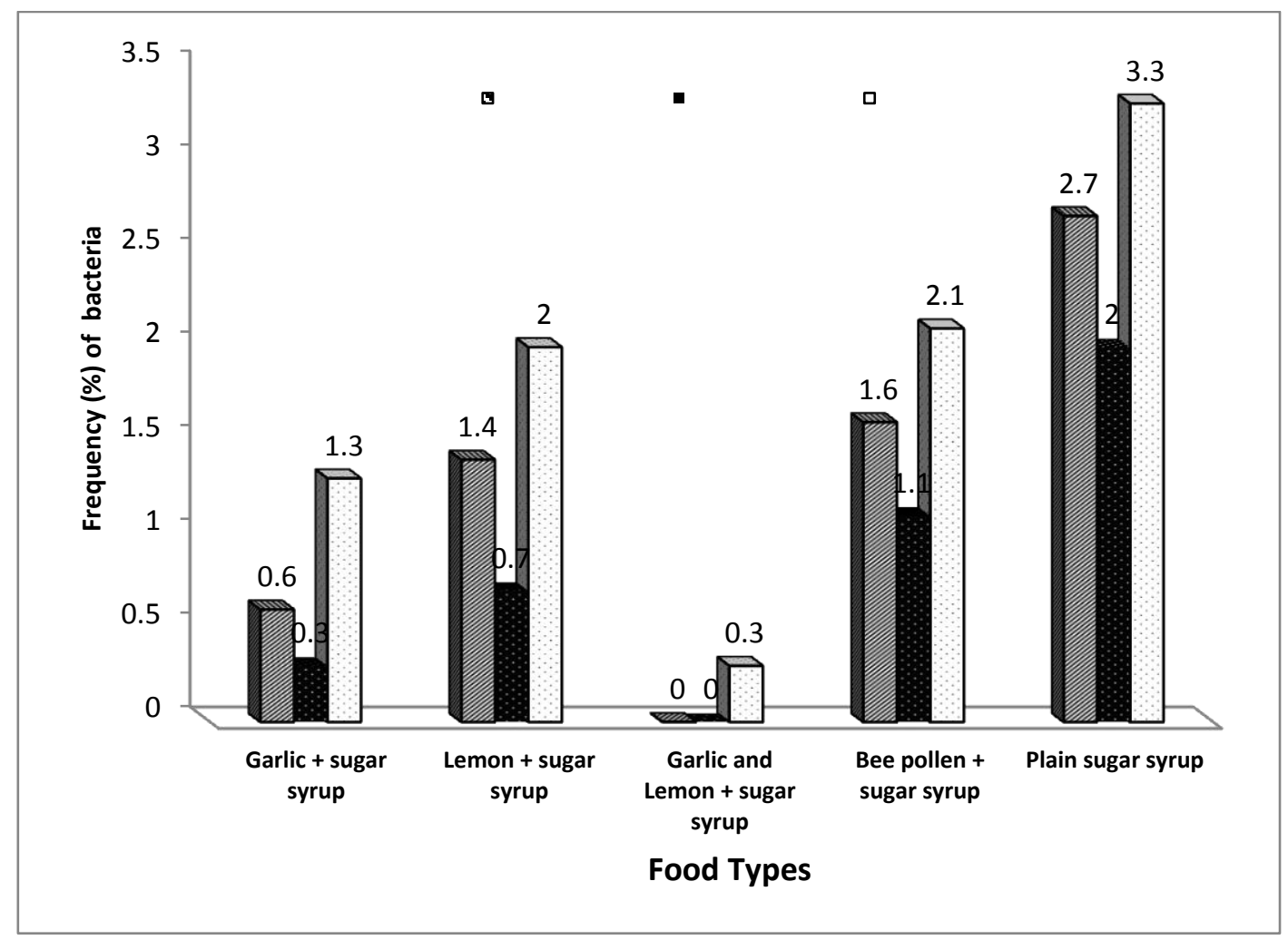

Fig. 2. Relationship between frequency (\%) of bacteria in honey samples collected from honeybee colonies fed on different food types.

botulism), four fungi types (Aspergillus apis, Aspergillus niger, Cladosporium sp. and Penicillium sp.) and three yeasts types (Debaromyces sp., Lipomyces sp. and Saccharomyces sp.) were determined according to cultural, morphological and physiological characters. Cladosporium botulism bacterium was the most frequency compared with other bacteria types, where the percentages of frequency were $(0.3-3.3,0.0-2.7$ and $0.0-$ $2.0 \%)$ for $C$. botulism, B. brevis and B. cereus, respectively (Fig. 2). Meanwhile, Aspergillus apis fungus was the most frequency compared with other fungi types, where the percentages of frequency were $(0.0-3.1,0.0-2.4$ and $0.0-0.6 \%)$ for $A$. apis, $A$. niger and Cladosporium sp. and Penicillium sp., respectively (Fig. 3). The data also summarized that Lipomyces $\mathrm{sp}$. was the most frequency compared with other yeasts types, where the percentages of frequency were $(0.4-2.9,0.0$ -2.1 and $0.0-1.40 \%$ ) for Lipomyces sp. Debaromyces sp. and Saccharomyces sp., respectively (Fig. 4). Meanwhile, Saccharomyces sp. yeast, Penicillium sp., Cladosporium sp. and A. niger fun- gi and $B$. cereus bacterium were the least frequency compared with other microorganisms, where percentages of frequency were $(0.0-0.1,0.0-$ 1.1 and $0.0-1.1 \%$ ), respectively, but $B$. brevis bacterium and Debaromyces $\mathrm{sp}$ yeast were moderately frequency compared with other microorganisms, where percentages of frequency were $(0.0-$ 1.6 and $0.0-1.3 \%$ ), respectively.

Sinacori et al (2014) showed that microbial population of nectar honey and honeydew honey samples were presence of 13 species of bacteria, 5 of yeasts and 17 of filamentous fungi. The species most frequently isolated were Bacillus amyloliquefaciens, Zygosaccharomyces melis, and Aspergillus niger for the three microbial groups, respectively. There are several reports about the presence of Clostridium botulism spores in honey. Aureli et al (2002) and Midura et al (1979) described the methods for the isolation of $C$. bolutinum from honey samples (9/90 i.e. 9 samples out of 90 samples); Nakano and Sakaguchi (1991) concluded that many spores of $C$. bolutinum were detected in different containers of honey product; 


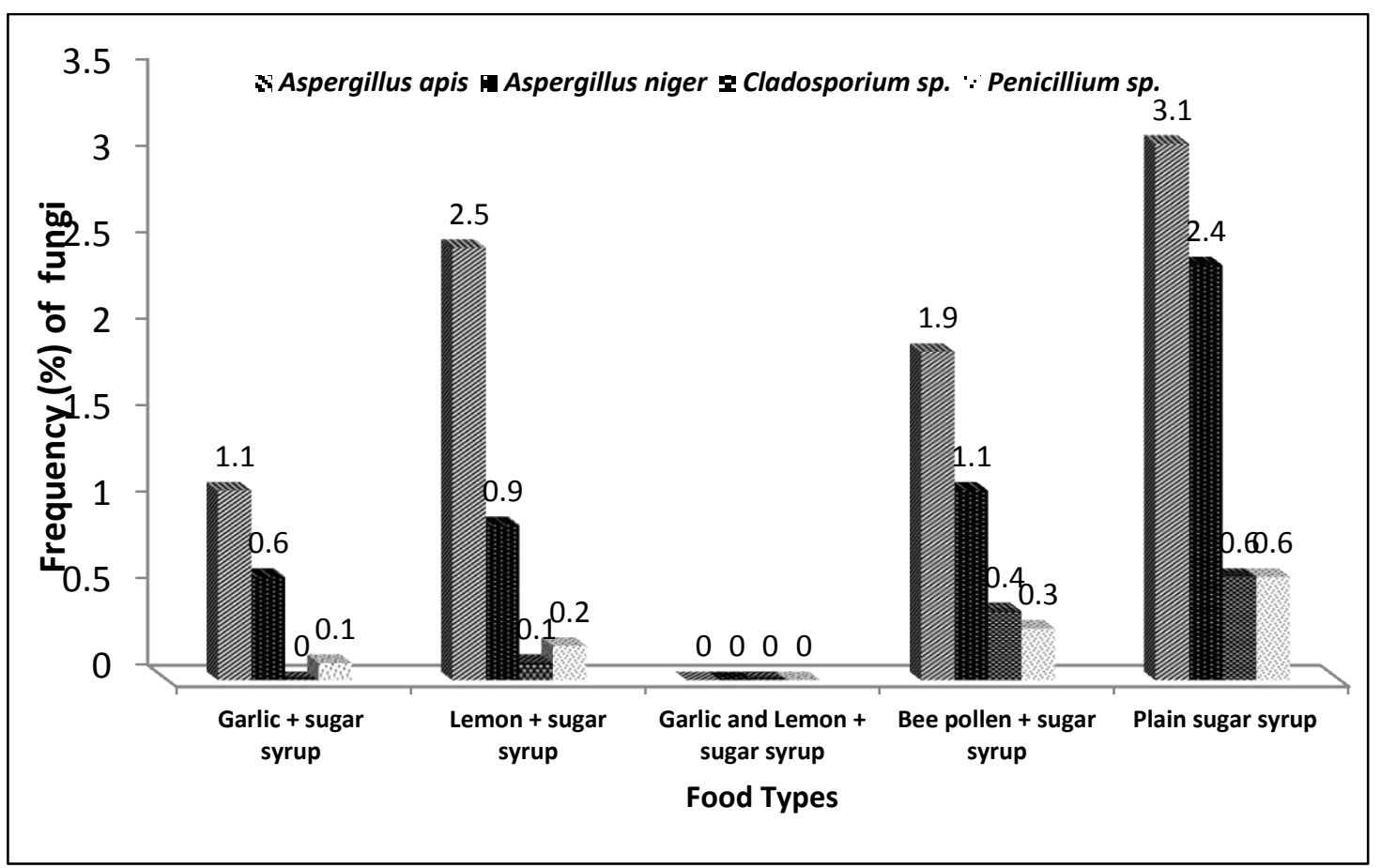

Fig. 3. Relationship between frequency (\%) of fungi in honey samples collected from honeybee colonies fed on different food types.

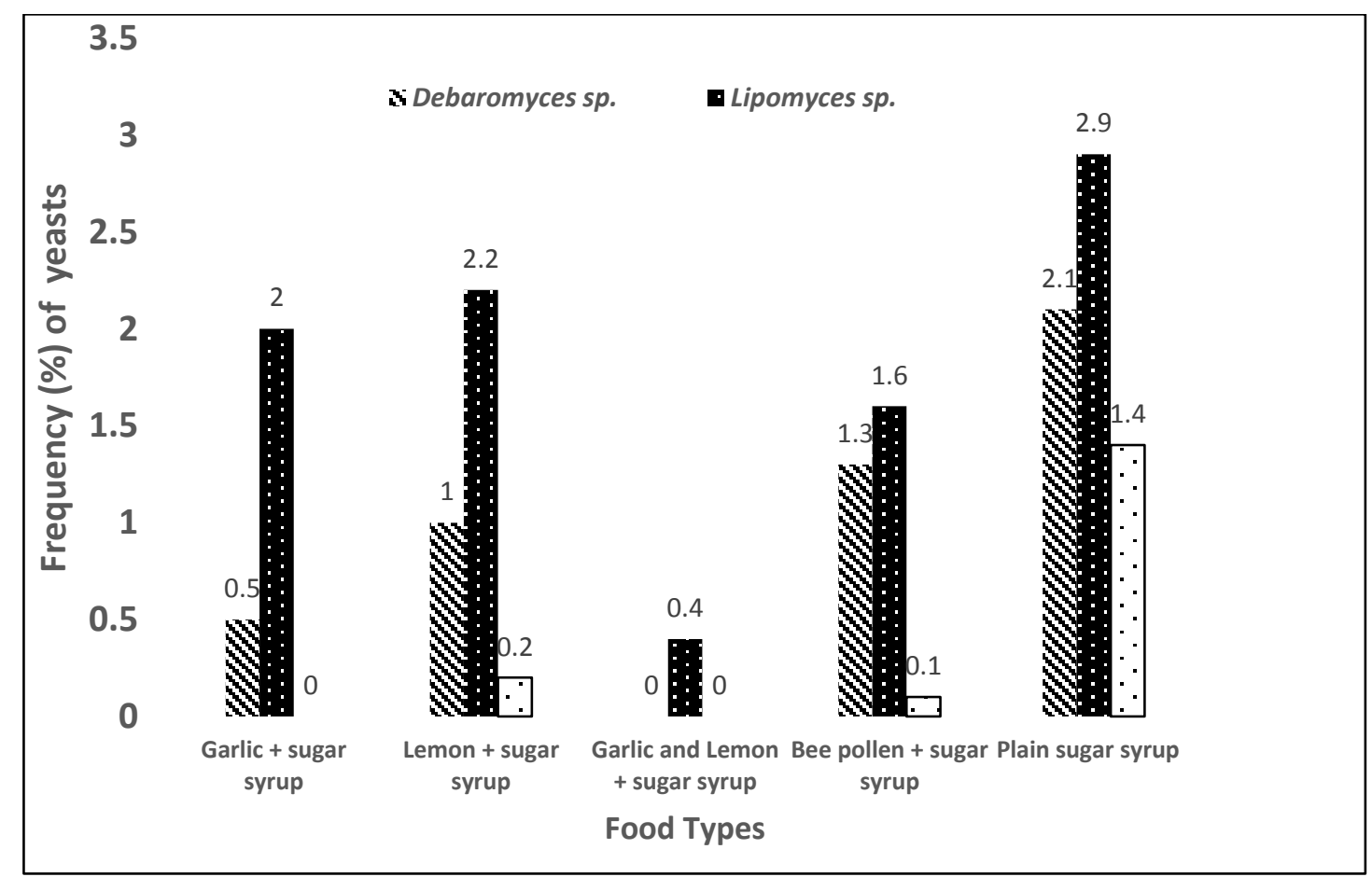

Fig. 4. Relationship between frequency (\%) of yeasts in honey samples collected from honeybee colonies fed on different food types. 
Nakano et al (1992) detected type A, B and C of Clostridium spores in $3 / 56$ samples. They also found $C$. bolutinum type $A$ in 2/77 honey samples of rural producers. Schocken-lturrino et al (1999) found 6/85 honey samples and Cox and Hinkle (2002) found that up to $25 \%$ of the honey products contain spores of $C$. bolutinum. Nevas et al (2002) mentioned that spores of $C$. bolutinum were detected in 8/114 of the fresh honey and 12/76 imported honey samples.

\section{REFERRENCES}

Aizen, M.A., Garibaldi, L.A., Cunningham S. A. and Klein, A.M. 2008. Long-term global trends in crop yield and production reveal no current pollination shortage but increasing pollinator dependency. Current Biology 18(20), 15721575.

Aureli, P., Franciosa, G. and Fenicia, L. 2002. Infant botulism and honey in Europe: a commentary. Pediatr. Infect. Dis. J., 21, 866-868.

Barnett, H.L. and Hunter, B.B. 1987. Illustrated Genera of imperfect Fungi. Burgress Co., Minneapolis, Minnesota, USA, 241pp.

Barnett, J.A., Payne, R.W. and Yarrow, D. 2000. Yeasts characterization and identification. Cambridge University Press, Cambridge, UK, $351 \mathrm{p}$.

Bochner, B.R. 1991. Identification of over 500 Gram-negative species by a single test panel. American Clinical Laboratory, $14 \mathrm{p}$.

Cox, N. and Hinkle, R. 2002. Infant botulism," American Family Physician, 65(7), 13881392.

Estevinho, L.M., Feas X., Seijas J.A. and Vazquez-Tato, M.P. 2012. Organic honey from Tras-Os-Montes region (Portugal): chemical, palynological, microbiological and bioactive compounds characterization. Food and Chemical Toxicology, 50(2), 258-264.

Fahy, A.C. and Persley, G.T. 1983. Plant Bacteria Diseases; A Diagnostic Guide. Academic Press, New York, USA, 393 p.

Kim, S.A., Oh, S.W., Lee Y.M., Imm, J.Y., Hwang, I.G., Kang, D.H. and Rhee, M.S. 2011. Microbial contamination of food products consumed by infants and babies in Korea. Lett. Appl. Microbiol.; 53, 532-538.

Kreger-Van Rij, N.I.W. 1984. The yeasts: A taxonomic study, $3^{\text {rd }}$ Ed., Elsevier Science Publishers, Amsterdam, Netherland, 301 p.
Matos, I.T.S.R., Nunes, M.T., Mota, D.A., Laureano, M.M.M. and Hoshiba, M.A. 2011. Microbiological quality of honey from Melipona sp. produced in central Amazon rainforest (Parintins-AM-Brazil). Revista Verde de Agroecologia e Desenvolvimento Sustentavel, 6(4), Artigos 91-95.

Mehrotra, N.K., Sharma, N., Ghosh, R. and Nigam, M. 1996. Biological control of green and mould disease of citrus fruit by yeasts. Indian Phytopathol. 49, 350-354.

Midura, T.F., Snowden, S., Wood, R.M. and Arnon S.S. 1979. Isolation of Clostridium botulinum from honey," J. Clinical Microbiology, 9(2), 282-283.

Nakano, H. and Sakaguchi, G. 1991. An unusually heavy contamination of honey products by Clostridium botulinum type $\mathrm{F}$ and Bacillus alvei," FEMS Microbiology Letters, 79(2-3), 171-177.

Nakano, H., Yoshikuni, Y., Hashimoto, H. and Sakaguchi, G. 1992. Detection of Clostridium botulinum in natural sweetening. International J. Food Microbiology, 16(2), 117-121.

Nevas, M., Hielm, S., Lindstr"om, M., Horn, H., Koivulehto K. and Korkeala, H. 2002. High prevalence of Clostridium botulinum types $\mathrm{A}$ and $B$ in honey samples detected by polymerase chain reaction," International Journal of Food Microbiology, 72(1-2), 45-52.

Odds, F.C. 1988. Candida and Candidosis, $2^{\text {nd }}$ Ed., Bailliere Tindall, London, UK, 189 p.

Olaitan, P.B., Adeleke O.E. and Ola, I.O. 2007. Honey: a reservoir for microorganisms and inhibitory agent for microbes. Afr. Health Sci., 7, 159-165.

Olivieri, C., Marota I., Rollo, F. and Luciani, S. 2012. Tracking plant, fungal, and bacterial DNA in honey specimens. J. Forensic Sci., 57, 222227.

Piana, M.L., Poda, G.; Cesaroni, D., Cuetti, L., Bucci, M.A. and Gotti, P. 1991. Research on microbial characteristics of honey samples of Udine province. Riv. Sot. Ital. Sci. Aliment., 20, 293-301.

Rozanska, H. and Osek, J. 2012. Effect of storage on microbiological quality of honey. Bulletin of the Veterinary Institute in Pulawy; 56(2), 161-163.

Schaad, N.W. 1980. Laboratory guide for identification of plant pathogenic bacteria. The American Psychopathological Society, St. Paul, Minnesota, USA, 72 p. 

of extracted honey with microorganisms

Schocken-Iturrino, R.P., Carneiro, M.C., Kato E., Sorbara J.O.B., Rossi, O.D. and Gerbasi L.E.R. 1999. Study of the presence of the spores of Clostridium botulinum in honey in Brazil," FEMS Immunology and Medical Microbiology, 24(3), 379-382.

Sinacori, M., Francesca N., Alfonzo, A., Cruciata, M.; Sannino, C., Settanni, L. and Moschetti, G. 2014. Cultivable microorganisms associated with honeys of different geographical and botanical origin. Food Microbiology; 38:284-294 (AN: 20143057031).
Sndecor, G. W. and Cocheran, W.G. 1990. Statistical Methods, $7^{\text {th }}$ Ed., lowa State University Press, Ames, lowa, USA, 507 pp.

Snowdon, J.A. and Cliver, D.O. 1996 Microorganisms in honey. Int. J. Food Microbiol. 31, 1-26.

Tanzi, M.G. and Gabay, M.P. 2002. Association between honey consumption and infant botulism. Pharmacotherapy; 22, 1479-83.

Whadan, H.A. 1998. Causes of the antimicrobial activity of honey. Infection, 26, 26-31. 